\title{
EIGHT YEARS AND 2500 MANUSCRIPTS LATER...
}

\section{S Sharma}

Time does fly when you are enjoying yourself. It is hard to believe that eight years have passed since Indian Journal of Medical Microbiology (IJMM) editorial office began functioning at LV Prasad Eye Institute in November 2000. Although it seems like just yesterday, a lot has taken place in the years that have gone by. The journal finds itself in the distinguished company of other peer-reviewed journals in databases such as PubMed, EMBASE, IndMed and Science Citation Index Expanded. It enjoys the attention of over 300 reviewers and in addition to the readership of over 2000 medical microbiologists its website receives hits in thousands, the top three articles being, Edible Vaccines: Current Status and Future $(35,771)$, Quality Control of Culture Media in a Microbiology Laboratory $(29,747)$ and Chikungunya Fever: A Re-emerging Viral Infection $(27,395)$. It is hoped that the journal will continue to widen its impact.

One of the most gratifying achievements for IJMM in last few years has been the journal's website and the manuscript tracking system on 'journalonweb'. The efficiency of Medknow Publications in maintaining and improving these websites from time to time has been a particular source of strength. The website is an open URL which enables easier linking, searching and indexing. Full text articles or abstracts in the journal from 1993 onwards have been made available on the website. Now, the abstracts and full texts of the cited references have been directly linked and these can be accessed at the click of mouse. The website provides statistical data such as number of users online, number of visitors since a predetermined date and data regarding article downloads.

The past years have witnessed efforts by the editorial board to improve the peer-review process. The support of editorial board members has extended much beyond review of manuscripts. The journal could not have been managed without the untiring efforts of the assistant editors in raising funds. A special mention must be made of Dr. V. Lakshmi, NIMS, Hyderabad. The high quality of our published articles reflects our board members' industriousness and intellectual prowess. The hundreds of additional reviewers, to whom I express my deeply felt gratitude and who are listed by name in each October issue, must also share the credit. Without their careful appraisals, the IJMM could not have succeeded. During the initial years of my tenure, I have

(email: <savitri@lvpei.org>)

LV Prasad Eye Institute, Bhubaneswar-751 024, Orissa, India been the recipient of extraordinary service from one talented administrative assistant, K Sridevi, who identified herself with the journal as much as I did, if not more. Much of the credit for regular publication of the journal prior to joining Medknow Publications goes to her.

Dr. Gullapalli N Rao, the chairman of LV Prasad Eye Institute (LVPEI) and Dr. Taraprasad Das, the director of LVPEI, Bhubaneswar, provided unstinted institutional support for the journal which is in line with the principle of high academic standards of the LVPEI system. I thank them on behalf of the Indian Association of Medical Microbiologists.

During the past eight years, we have made some revisions and additions to the existing sections in the journal. These include special articles and research snippets; we hope that readers have enjoyed them. No doubt, the future editor will make many more changes in the format. After a period of some years, revision of journal style and content is healthy and necessary and with her keen sense of style Dr. Reba Kanungo is sure to add welcome colours to the journal.

After being 'wedded' to the journal all these years, I am bound to miss receiving the daily load of mails and thoughtprovoking manuscripts. I will also miss selecting reviewers for manuscripts, contemplating their evaluations, mulling over each manuscript's results (and the interpretation of those results), anticipating revisions, worrying about broken hearts while rejecting articles and receiving an eagerly awaited gift which felt like a new baby - the final printed version of IJMM. These activities occupied a large chunk of my Sundays, holidays, evenings and nights-I will surely feel the vacuum! Editing of the selected manuscripts and formatting the articles to the style of the journal, kept me tied to the laptop at airports and hotel rooms and I never knew how time flew- Most definitely, I will feel the vacuum.

Relieved of the routine editorial responsibilities, however, I anticipate having substantially more time to savour both the style and content of each issue from a readers' perspective. Being no more privy to the exciting new information in advance, I will anxiously await the new issue in print and on the website and look at it with a nostalgia that will stay with me forever. I will read it at the earliest and hope all readers of IJMM will do the same.

From November 1, 2008, Dr. Reba Kanungo of Pondicherry Institute of Medical Sciences, Pondicherry 
will take the Editor's reins with my sincere best wishes and continuing enthusiastic support. Dr. Kanungo and I have had the privilege of working together on the journal for several years in the past and the transition already seems easy and smooth. Her passion for shouldering editorial responsibilities matches mine and that will add miles to this great voyage.
The editorship of IJMM has been both a privilege and a joy. I gratefully acknowledge the contribution of my predecessors and peers for their part in the process.

Source of Support: Nil, Conflict of Interest: None declared.

\section{Author Help: Online Submission of the Manuscripts}

Articles can be submitted online from http://www.journalonweb.com. For online submission articles should be prepared in two files (first page file and article file). Images should be submitted separately.

\section{1) First Page File:}

Prepare the title page, covering letter, acknowledgement, etc., using a word processor program. All information which can reveal your identity should be here. Use text/rtf/doc/pdf files. Do not zip the files.

\section{2) Article file:}

The main text of the article, beginning from Abstract till References (including tables) should be in this file. Do not include any information (such as acknow ledgement, your names in page headers, etc.) in this file. Use text/rtf/doc/pdf files. Do not zip the files. Limit the file size to $400 \mathrm{~kb}$. Do not incorporate images in the file. If file size is large, graphs can be submitted as images separately without incorporating them in the article file to reduce the size of the file.

3) Images:

Submit good quality colour images. Each image should be less than $\mathbf{4 0 0} \mathbf{~ k b}$ in size. Size of the image can be reduced by decreasing the actual height and width of the images (keep up to about 4 inches) or by reducing the quality of image. All image formats (jpeg, tiff, gif, bmp, png, eps, etc.) are acceptable; jpeg is most suitable. The image quality should be good enough to judge the scientific value of the image. Alw ays retain a good quality, high resolution image for print purpose. This high resolution image should be sent to the editorial office at the time of sending a revised article.

4) Legends:

Legends for the figures/images should be included at the end of the article file. 